\section{TLR2 Signaling Pathway in Alveolar Bone Osteogenesis Induced by Aloe vera and Xenograft (XCB)}

\author{
Utari Kresnoadi ${ }^{1}$, Retno Pudji Rahayu ${ }^{2}$, M Rubianto ${ }^{3}$, Subijanto Marto \\ Sudarmo ${ }^{4}$, Hendrik Setia Budi ${ }^{5}$
}

\author{
'Prosthodontic Department, Dental \\ Medicine Faculty, Universitas \\ Airlangga, Surabaya, Indonesia \\ ${ }^{2}$ Oral Patologic Department, Dental \\ Medicine Faculty, Universitas \\ Airlangga, Surabaya, Indonesia \\ ${ }^{3}$ Periodontic Department, Dental \\ Medicine Faculty, Universitas \\ Airlangga, Surabaya, Indonesia \\ ${ }^{4}$ Pediatric Department, Medicine \\ Faculty, Universitas Airlangga, \\ Surabaya, Indonesia \\ ${ }^{5}$ Oral Biology Department, Dental \\ Medicine Faculty, Universitas \\ Airlangga, Surabaya, Indonesia
}

Correspondence: Utari Kresnoadi, Jl. Prof Dr Moestopo 47, Surabaya, Indonesia. Tel.:+62 8123274014. e-mail: ut.kres@yahoo.com

Key Words: Aloe vera, alveolar bone, osteogenesis, TLR2, XCB.

\section{Introduction}

Adequate alveolar bone is required to achieve a stable denture. Thus, prevention of residual ridge resorption is important during dental extraction, order to limit the progressive bone resorption, since the trauma caused by extraction can trigger inflammation that may stimulate alveolus bone resorption. In other words, if the socket is not preserved, the residual ridge resorption may occur progressively (1-3). Therefore, interim denture is commonly made after dental extraction for aesthetic reasons before the definitive denture. This method has been recognized as one of the factors that may induce a rapid alveolar bone resorption. The presence of denture in fresh extraction wound can cause trauma and subsequently trigger inflammatory process of the alveolar wound, so the effectiveness of wound healing will be reduced. As a result, this denture becomes irretentive and ultimately requires repeated relining (4).

Bone grafting procedure is a technique often used to repair either bone defects or ridge augmentation (5). However, failure of the procedure has been reported with various results. Graft materials used should have osteoconductive ability that potentially can stimulate the growth of new bone (6). Development of a new material is necessary to stimulate or accelerate bone growth activity.

Aloe vera is a natural material known as a biogenic stimulator and hormonal activity modulator during the wound healing. Fluid derived from Aloe vera may even prevent development of scar tissue after skin incision (7). The chemical composition of Aloe vera consists of aloin, aloe-emodin, barbaloin, amino acids and anthraquinones. Anthraquinones has several beneficial properties as antiinflammatory, analgesic, anti-microbial effect, as well as anesthetic and laxative effects (8). It is also known that another material found in Aloe vera, aloe-emodin, can both promote tissue healing and recovery processes and minimize pain (9).

TLR (Toll Like Receptor) is a protein that plays an important role in initiation of immune system. TLR, which has a specific molecular pattern found in a variety of microbial pathogens, such as bacteria and viruses, can also trigger inflammatory and antiviral responses as well as dendritic cell maturation to eliminate pathogenic agents (10). In addition, signaling pathway of botanical components can be identified by signaling marker derived from TLR-2 (11).

For those reasons, this study aimed to explore the role of a combination of Aloe vera and cancellous bovine xenograft material in stimulating alveolar bone growth and preventing alveolar bone resorption after tooth extraction. The effects of Aloe vera and XCB in activating TLR2 and increasing osteoblast, OPG, TNF $\alpha$ and colagen-1 levels might become the key properties contributing to the positive result since these substances are known to play important roles to promote the positive effect of osteoblast and suppress the negative effect of osteoclast during bone growth. 


\section{Material and Methods}

\section{Research Design and Animal Model}

This study was conducted on forty-eight healthy male guinea pigs (Cavia cobayas) aged 3-3.5 months and weighing around 300 to $350 \mathrm{~g}$. The use of those experimental animals was approved by the Ethical Clearance of Animal Care and Use Committee (ACUC) of Veterinary Faculty, Universitas Airlangga No. 003-KE/ TE, May 1, 2012. This research was conducted in the Biochemical Laboratory of the Medical Faculty, Universitas Airlangga.

Aloe vera used in this research was identified in the Biological Laboratory of the Faculty of Sciences and Technology, Universitas Airlangga on March 23, 2011. The identification process showed that Aloe vera kingdom is Plantae, Magnoliophyta division, class Liliopsida, order Liliales, family Liliaceae, Aloe genus and Aloe vera species. The used Aloe vera was extracted and freeze-dried in the Biological Laboratory.

The other used materials were sterile aquadest, cancellous bovine xenograft (XCB) (produced by the Bank of Tissues in Dr. Soetomo Hospital, Surabaya), absolute alcohol, 70\% alcohol, anti collagen 1, anti TLR2, anti osteoprotegerin (OPG) and anti-tumor necrosis $\vec{s}$ factor $\alpha$ (TNF- $\alpha$ ) reagent (Santa Cruz Biotechnology, Inc., Santa Cruz, CA, USA) monoclonal antibodies. In addition, immunostaining kit reagent (Leica Biosystems, Wetzlar, Germany) was used. Hematoxylin-eosin reagent, micropipette, tip (yellow, white, blue), light microscopy, object glass with polylysin coating and cover glass were also used for analysis of the specimen.

A randomized research design and post-test design were conducted for all the groups. Four different solutions were used as treatment for each group, namely solution containing polyethylene glycol (PEG) only, combination of $\mathrm{XCB}$ and $\mathrm{PEG}$, a combination of Aloe vera and PEG, and a mixture of $2 \%$ active substance containing Aloe vera, $\mathrm{XCB}$ and PEG. PEG was used as a carrier so that the mixture becomes a gel to facilitate filling into the socket.

Independent variables in this research were the mixture of Aloe vera $0.5 \mathrm{~g}, \mathrm{XCB} 0.5 \mathrm{~g}$ and $24 \mathrm{~g}$ PEG (PEG 4000+ PEG 400 , with ratio 1:1). The mixture of Aloe vera and XCB and PEG was manufactured in the Physical Chemistry Laboratory of Pharmacy Faculty, Universitas Airlangga. The dependent variables were TLR2, TNF $\alpha, \mathrm{OPG}$, Collagen 1 and expressions of osteoblast and osteoclast. The controlled variable was Cavia cobayas (guinea pig) with body weight of 300-350 $g$ at the age of 3-3.5 months. The animals were fed with corn, carrots and distilled water.

\section{Research Procedure}

The guinea pigs (Cavia cobaya) were divided into eight different groups based on the treatment and the time of examination after the treatment, whether it was 7 or 30 days after the extraction. Before their lower right incisors were extracted by using special pliers, they were anaesthetized intravenously with ketamin $0.2 \mathrm{cc} / 300 \mathrm{~g}$ body weight (12). The examination conducted 7 days after dental extraction, according to Werner and Grose (13), is because after 7 days the wound is healed and a new tissue is formed, called granulation tissue. Osteoid can also be seen at the bottom and periphery of the socket (14). The examination conducted 30 days after dental extraction is because after the fourth week the activity of osteoblast is maximal (14).

Next, the first two groups filled with PEG solution were classified as Group I which result was examined 7 days after the extraction and as Group II, which result was examined 30 days after. The second two groups filled with the combination of XCB and PEG solution were classified as Group III which result was examined 7 days after and as Group IV which result was examined 30 days after. The third two groups filled with the combination of Aloe vera and PEG were classified as Group V which result was examined 7 days after and as Group VI which result was examined 30 days after. Finally, the last two groups filled with the combination of Aloe vera, XCB and PEG solution were classified as Group VII which result was examined 7 days after, and as Group VIII which result was examined 30 days after. The amount of solution poured into each of the post dental extraction sockets in the lower incisor was $0.1 \mathrm{~cm}^{3}$ and they were sutured.

\section{Histopathological Specimen Preparation}

The guinea pigs were decapitated and their jaw was exposed for decalcification procedure using $2 \%$ nitric acid for approximately 14 days. Paraffin block preparation was made. Paraffin blocks about 4- $\mu$ m-thick were cut with rotary microtom and placed on glass object. The examination of specimen was conducted by making slide preparation used for eosin staining and immunohistochemical staining. TLR-2, TNF- $\alpha$, Osteoprotegerin (OPG), and collagen-1 were identified by immune histochemical examination. Indirect immunohistochemical examination could be conducted using primary and secondary antibodies. Histological examination was conducted to identify and quantify the number of osteoclasts and osteoblasts in the specimen. The tissue preparation used in this research was performed in Anatomical Pathology of Dr Soetomo Hospital. Immunohistochemistry was conducted in Biochemistry and Biomolecular Enginering Laboratory of Medical Faculty, Brawijaya University. The quantification of the expressions of TLR2, TNF $\alpha$, OPG, collagen 1, osteoblast and osteoclast was conducted by making each slide in the field of view enlarged with $1000 \times$ magnification as many as 10 field 
of view. The results of the calculations were entered in a worksheet and the means of the field of view were calculated.

\section{Statistical Analysis}

All results were written in the worksheet and calculated. The calculation results were tabulated. The resulting data were tested by Kolmogorov-Smirnov test and ANOVA. The data then were tested with Tuckey's HSD to compare the data among the groups, since the aim of this study is to find the role of TLR2 signaling pathway in reducing osteoclast activity and promoting osteoblast growth.

\section{Results}

The expressions of TLR2 and collagen- 1 as markers of osteoclasts as markers of bone resorption decreased. OPG was decreased (Fig. 1) in both examinations, at 7 days and

Table 1. Significantly treatment group after 7 days

\begin{tabular}{lcc}
\hline Groups & $\mathrm{F}$ & $\mathrm{p}$ \\
\hline TLR2 & 52.853 & .000 \\
OPG & 258.145 & .000 \\
Collagen 1 & 49.115 & .000 \\
TNF- $\alpha$ & 252.190 & .000 \\
Osteoclast & 67.571 & .000 \\
Osteoblast & 47.600 & .000 \\
\hline
\end{tabular}
osteoblasts increased, while the expressions of TNF $\alpha$ and

30 days. Statistical calculation results of ANOVA on the expressions of TLR2, TNF $\alpha$, OPG and collagen 1 in 7 days are in Table 1, while those in 30 days are in Table 2.

Based on the results of ANOVA on TLR2 after 7 and 30 days, there were significant differences in the expression of TLR2 between the control group and the treatment groups, each one induced with $\mathrm{XCB}$, Aloe vera or the combination of Aloe vera and $\mathrm{XCB}$, with $\mathrm{p}<0.05$ significance. Based on the results of HSD test, there were significant differences between the group induced with $\mathrm{XCB}$, the group induced with Aloe vera, and the group induced with the combination of Aloe vera and XCB with $p<0.05$.

Based on the results of ANOVA test on OPG after 7 and 30 days, there were significant differences in the expression of OPG between the control group and the treatment groups each one induced with $\mathrm{XCB}$, Aloe vera or the combination of Aloe vera and $\mathrm{XCB}$, with $\mathrm{p}<0.05$ significance. Based on the results of HSD test, there were significant differences

Table 2 . Significantly treatment group after 30 days

\begin{tabular}{lcc}
\hline Groups & $\mathrm{F}$ & $\mathrm{p}$ \\
\hline TLR2 & 117.686 & .000 \\
OPG & 29.930 & .000 \\
Collagen1 & 110.084 & .000 \\
TNF- $\alpha$ & 19.878 & .000 \\
Osteoclast & 79.455 & .000 \\
Osteoblast & 51.543 & .000 \\
\hline
\end{tabular}

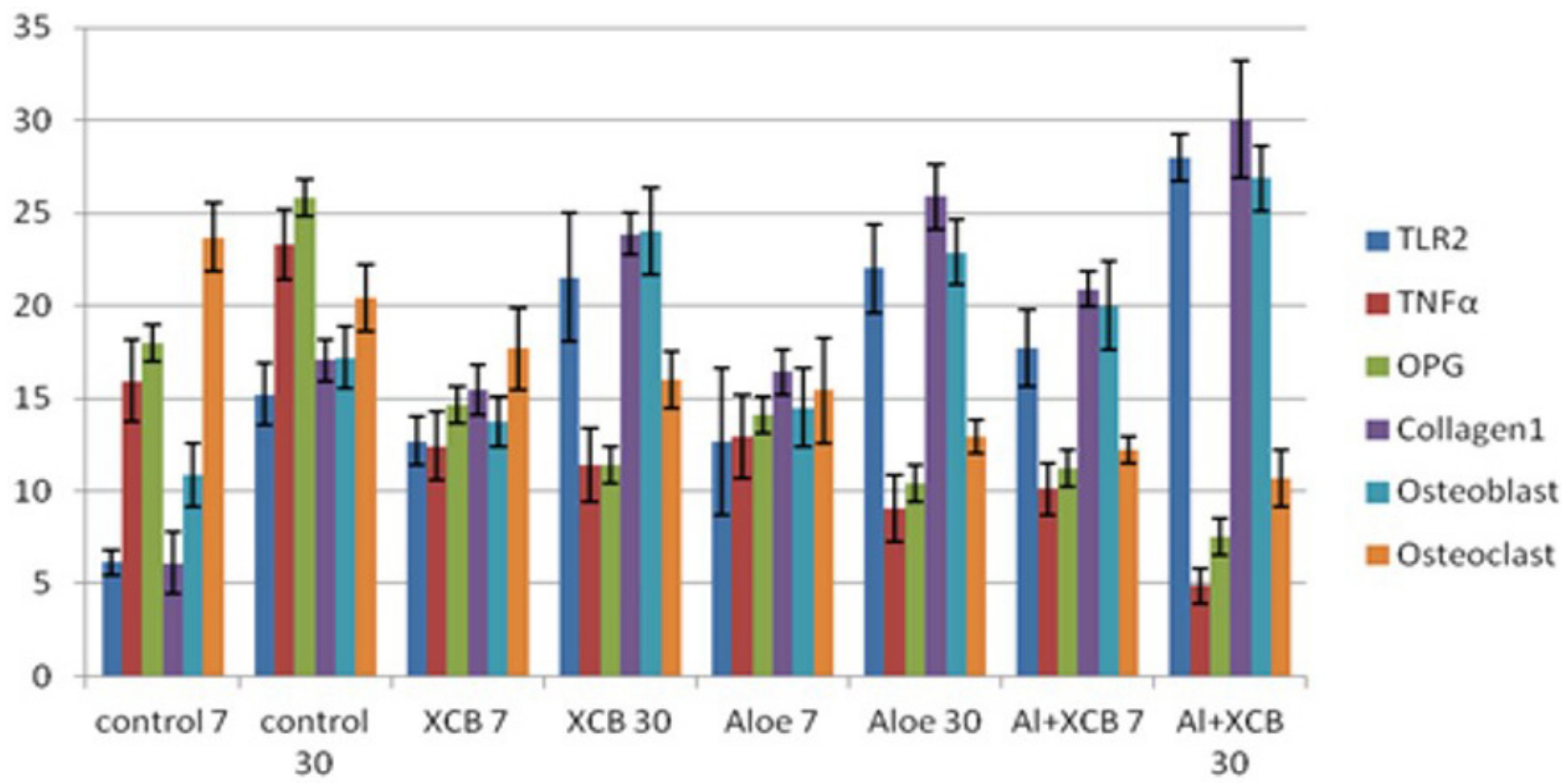

Figure 1. Mean and standard deviation of expression of each treatment group after 7 and 30 days. 
between the group induced with $\mathrm{XCB}$, the group induced with Aloe vera, and the group induced with the combination of Aloe vera and XCB, with $\mathrm{p}<0.05$.

Based on the results of ANOVA on TNF- $\alpha$ after 7 and 30 days, there were significant differences in the expression of TNF- $\alpha$ between the control group and the treatment groups each one induced with $\mathrm{XCB}$, Aloe vera or the combination of Aloe vera and $X C B$, with $p<0.05$ significance. Based on the results of HSD test, it is known that there were significant differences between the group induced with $X C B$, the group induced with Aloe vera and the group induced with the combination of Aloe vera and $\mathrm{XCB}$, with $\mathrm{p}<0.05$.

Based on the results of ANOVA on collagen 1 after 7 and 30 days, there were significant differences in the expression of collagen 1 between the control group and the treatment groups, each one induced with $\mathrm{XCB}$, Aloe vera or the combination of Aloe vera and $\mathrm{XCB}$, with $\mathrm{p}<0.05$ significance Based on the results of HSD test, there were significant differences between the group induced with XCB, the group induced with Aloe vera and the group induced with the combination of Aloe vera and $X C B$, with $p<0.05$.

The results of ANOVA on osteoblasts and osteoclasts after 7 and 30 days, show significant differences in the expressions of osteoblasts and osteoclasts between the control group and the treatment groups each one induced with $\mathrm{XCB}$, Aloe vera or the combination of Aloe vera and $X C B$, with $p<0.05$ significance The results of HSD test showed significant differences between the group induced
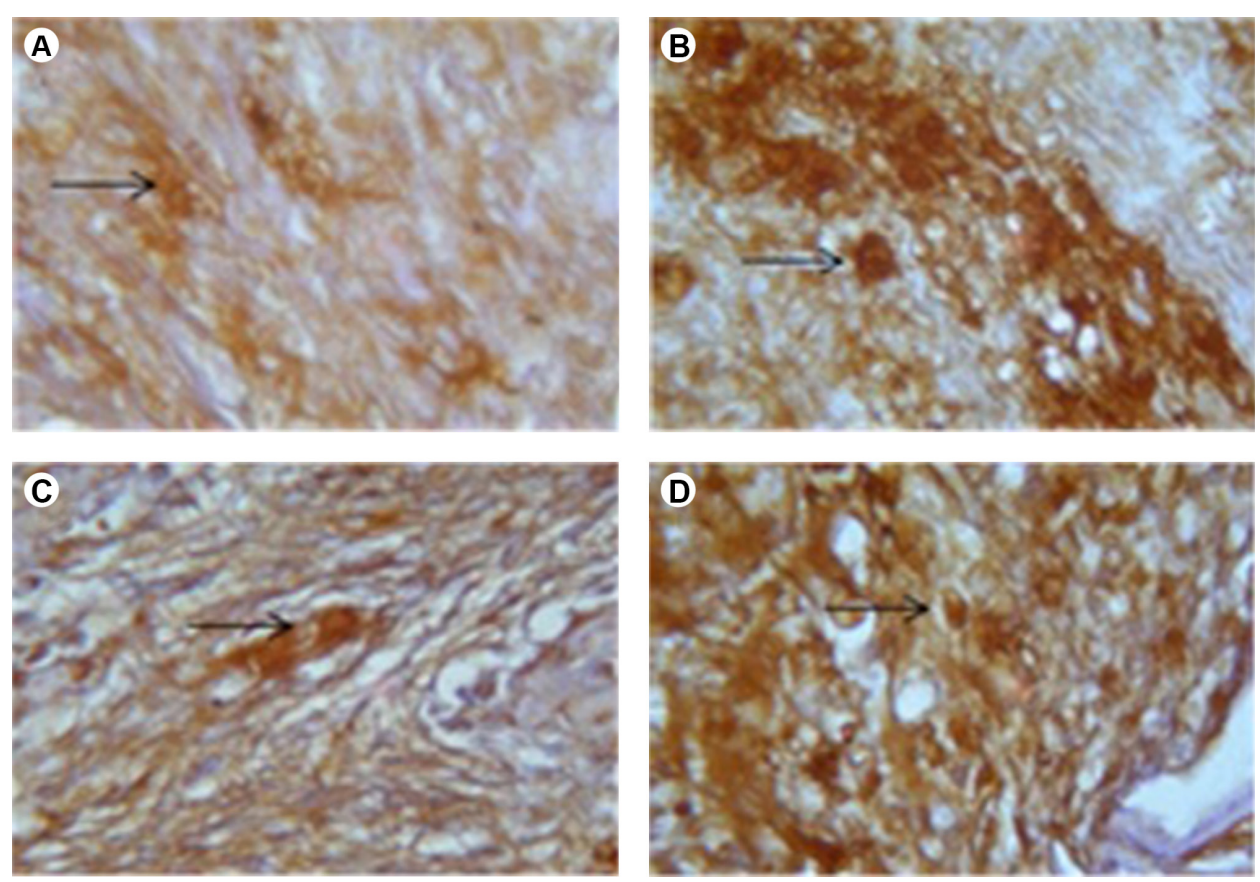

Figure 2. Microscopic image of TLR2, 30 days after examination. A: Control. B: Filling with xenograft. C. Filling with Aloe Vera. D: Filling with a combination of Aloe vera and Xenograft. The arrows indicate TLR2 expression. 
(OPG) expression occurred because OPG bound to the Receptor Activator of Nuclear factor- $\kappa \beta$ ligand (RANKL) played a role, and then the rest of the OPG bound to RANKL was non-detectable monoclonal anti-OPG and OPG was decreased. OPG stimulated by fibroblast usually stimulates the transformation of RANKL into RANK (18). During the inflammation process, fibroblast tissue stimulates OPG which inhibits the binding of RANKL-RANK and triggers the activities of FGF-2. FGF-2 is a family of growth factors that control proliferation and differentiation of osteoblast cells and has a potential mitogenic effect in osteoprogenitor cells that affect bone metabolism and regulation of proliferation and differentiation of osteoblast cells (19).

Osteoclast Activating Factor (OAF) also plays an important role during the bone resorption process. OAF plays an important role in the mechanism of continuous resorption series and a series of prostaglandin synthesis will also exacerbate the resorption process. This condition will inhibit the osteoblast activity and bone formation process. The identification process of IL-1 (Interleukin-1) on its activity in bone resorption stimulation as well as TNF- $\alpha$ and IL- 6 activities were also found in this study. TNF- $\alpha$ and IL-1 were marked as two cytokines playing important roles in inflammatory responses. TNF- $\alpha$ activity was involved in inducing RANKL activity. TNF $\alpha$ and IL1 $\beta$ known as proinflammatory cytokines have an effect in reducing periodontal bone regulated by the expressions of RANKL and OPG $(1,2)$.

Healing phase after dental extraction, in addition, occurs both in mucosal tissue and alveolar bone tissue. The sequence of wound healing after tooth extraction, according to Werner and Grose (13) is as follows: on the first day, the wound will be filled with clotted blood and followed by the invasion of neutrophils cell into the blood clot. Three to seven days after tooth extraction, apoptosis process can be seen in neutrophil cells and then followed by abundant macrophage cells in wound tissues. Endothelial cells migrate into the clot; they proliferate and form new blood vessels. Fibroblasts migrate into the wound tissue, where they proliferate and deposit extracellular matrix. The new tissue is called granulation tissue. Keratinocytes proliferate at the wound edge and migrate down the injured dermis and above the provisional matrix. One to two weeks after dental extraction the wound is completely filled with granulation tissue. Fibroblasts were transformed into myofibroblasts, leading to wound contraction and collagen deposition. The wound is completely covered with a neoepidermis (13).

In this study the treatment groups induced with Aloe vera had higher expressions of TLR2, collagen 1 and osteoblasts than those induced with XCB. A possible explanation is that there are some components in Aloe vera, namely aloin, aloe emodin and barbaloin which have anti-inflammatory, antibacterial and anti-virus properties that can reduce inflammation caused by dental extraction trauma and subsequently induce the wound healing process. It can also trigger the stimulation of fibroblast and osteoblast tissues growth $(8,15-17)$. This phenomenon could also be triggered by aloeride, as polysaccharides found in Aloe vera have high molecular weight, as well as a very strong immunostimulator activity (20).

Thus, induction of the combination of Aloe vera and XCB produced the best results as indicated by the expressions of TLR2, collagen 1, osteoblasts, during 7 to 30 days of the healing process. As a result, the increased expressions will accelerate wound healing revocation, prevent inflammation and induce new bone growth. Aloe vera has anti-inflammatory effects because it contains carbohydrates: pure mannan, acetyl glukomanan, alkaline phosphatase enzyme and bradikinase, which has an antiinflammatory effect. In addition, it also contains auxin hormone, gibberellin and saponins, which function as both hormone stimulating healing and proteins, which can accelerate healing process, stimulate the growth of tissue, or increase in bone growth $(7,21)$. Thus, when Aloe vera is combined with cancellous bovine xenograft (XCB), it will function as an osteoinduction that will accelerate the healing process and new bone growth $(6,22)$.

Young-Kyung Ko (23) also finds that osteoprotegerin (OPG) is secreted as glycoprotein and one of TNF- $\alpha$ family by fibroblast cells with its function to suppress bone resorption and to inhibit osteoclastogenesis. Therefore, osteoprogerin does not directly relate to osteoblast cells. It is also known that OPG also acts as a decoy receptor that inhibits RANKL activity of osteoclast cells $(18,21)$.

TNF $\alpha$ is a proinflammatory cytokine that is regulated by the expression of RANKL and OPG. Therefore, OPG is a decoy receptor that inhibits RANKL binding to RANK. As a result there is no direct relation between TNF $\alpha$ and osteoclast cells since osteoclast cells do not have receptors with TNF $\alpha$. Similarly, Nancy and Bosshardt (24) also indicate that TNF $\alpha$ and IL 1 are two proinflammatory cytokines that have important roles in decreasing periodontal bone regulated by the expression of RANKL and OPG.

Steiner et al. (25) found that a week after dental extraction, the tissue composes fibrin, so early degeneration of granulation tissue occurs. The development of fibrin tissue then will change into granulation tissue containing blood vessels, fibroblast cells and chronic inflammatory cells. Thus, 8 days after dental extraction, new bone formation is observed throughout the alveolar bone, some of which is not on the wall socket, but on the surface of the socket trace revocation. At 12 days revocation, a new bone is formed along the wall socket and trabecular spaces 
around revocation area. Then, there will be bone trabeculae woven in socket rim. Osteoprogenitor cells, osteoblast cells and preosteoblast cells are surrounded by the trabeculae. Figure 2 shows that collagen 1 was increased, followed by the increase of osteoblasts. It means that there was a significant relation between osteoblast cells and collagen 1. In other words, collagen 1 could be considered as the product of osteoblasts since most of the results of osteoblast cells were collagen type-1, which then would form collagen fibrils. Besides that, osteoblast cells can also synthesize other proteins in bone matrix, such as osteocalcyn and osteonectin as 40-50\% non-collagen proteins in bone (26).

There was an inverse relation between osteoblast and osteoclast. In other words, if osteoclast cells increased, the growth of osteoblast cells would decrease due to the homeostasis of bone cells. Similarly, some researchers also state that osteoclast cells are responsible for bone resorption, while osteoblast cells form new bone $(18,27)$. Thus, it can be said that the preservation of socket after dental extraction by using the combination of Aloe vera and $\mathrm{XCB}$ is necessary for the preparation of oral rehabilitation in order to get a prominent ridge.

In summary, the role of TLR-2 can be considered as good signaling pathway in reducing osteoclasts during the process of alveolar bone osteogenesis, in preventing bone resorption, as well as in stimulating the growth of osteoblasts as a new bone by using the combination of Aloe vera and XCB.

\section{Resumo}

0 objetivo deste estudo foi investigar o papel da via de sinalização de TLR2 na redução da atividade osteoclástica e na promoção do crescimento de osteoblastos, induzindo uma combinação de Aloe vera e enxerto de osso esponjoso bovino (EOEB) em alvéolo de extração dentária. Quarenta e oito Cavia cobayas foram utilizados e divididos em 8 grupos $(n=6)$. Para o grupo de controle, seus incisivos mandibulares foram extraídos e preenchidos com polietilenoglicol (PEG). Para grupos de tratamento, os dentes foram extraidos e preenchidos com EOEB, Aloe vera e a combinação de Aloe vera e EOEB. Os primeiros quatro grupos foram sacrificados após 7 dias e os outros grupos após 30 dias. As análises de imunohistoquímica e histopatologia foram realizada para examinar TLR2, TNF $\alpha$ OPG, colágeno-1 e as expressões de osteoblastos e osteoclastos. Houve maior expressão de TLR2, FGF2, OPG e colágeno-1, bem como maior número de osteoblastos. Enquanto isso, a expressão de TNF $\alpha$ e osteoclastos estava diminuída. 0 principal achado do estudo foi que a via de sinalização de TLR2 influenciou o processo de osteogênese do osso alveolar, reduzindo a atividade dos osteoclastos e estimulando o crescimento de osteoblastos induzido pela combinação de Aloe vera e EOEB.

\section{References}

1. Lorenzo, J, Interaction beetwen immuno and bone cells: new insight with many remaining question. J Clin Invest 2000;106:749-752.

2. Winkler S. Implant site development and alveolar bone resorption patterns. J Oral Implantol 2002;28:226-229.

3. Fickl S, Zuhr O, Wachtel $H$, Kebschull M, Hurzeler MB. Hard tissue alteration after socket preservation with additional buccal overbuilding : a study in beagle dog, J Clin Perodontol 2009;36:898-904.

4. Iowa University, College of Dentistry. Immediate denture. 2011, accessed December 31, 2012

5. Lieberman JR, Friedlaender GE, Bone regeneration and repair. 1st. ed, Humana Press, Totowa-New Jersey; 2005.p. 22-32.

6. Munadziaroh $\mathrm{E}_{1}$ Hendriyantini $\mathrm{N}$, Indrasari M. To prevent high alveolar bone post extraction teeth with demineralized freeze dried bone allograft. J Dent Sci 2002;321-342.

7. Roostita \&t Editor team of Qanita. Lidahbuaya, 1st ed, Qanita Publishing, PT. Mizan Pustaka, Bandung, Indonesia. 2008;19-38.

8. Young Park MY, Hoon -Jeong Kwon HJ, Sung MK. Evaluation of aloin and aloe -emodin as anti inflammatory agents in aloe by using murine macrophages. Biosci Biotechnol Biochem 2009;73:828-832.

9. Marthanthi R. Toxicity test of Aloe vera gel 100\% freeze drying methods towards fibroblast cells on incubation time. (Thesis), Faculty of Dentistry, Airlangga University, Surabaya, Indonesia,2007: p. 10.

10. Kawai T, Akira S. TLR Signaling. Cell Death Differ 2006;13:816-825.

11. Pugh ND, Tamta $H$, Balachandram $P$, Xiangmei $W u$, Howell $J L$, Dayan FE, Pasco DS. The majority of in vitro macrophage activation exhibited by extract of some immune enhancing botanicals is due to bacterial lipoproteins and lipopolysaccharides, Int Immunopharmacol 2008;8:1023-1032.

12. Kusumawati, D. Bersahabat dengan hewan coba (Friends with animal experiment), 2004, 1st ed. Gajahmada University Press, Yogjakarta.

13. Werner $\mathrm{S}$, Grose R. Regulation of wound healing by growth factor and cytokin. Physiol Review 2003;83:835-866.

14. Chen ST, Wilson TG, Hammerle CHS. Immediate or early placement of implants following tooth extraction: review of biologic basic, clinical procedure and outcomes. The International Int J Oral Maxillofac Implants 2004;19S:12-25

15. Hamman JH. Composition and application of Aloe vera leaf gel. Molecule 2008;3:1599-1616.

16. Verma SM, Verma SK. Aloe vera their chemicals composition and applications: A review. Int J Biol Med Res 2011;2:466-471.

17. Agarry 00, Olaleye MT, Bello-Michael CO. Comparative antimicrobial activities of Aloe vera gel and leaf. Afr J Biotechnol 2005;4:1413-1414.

18. Lorenzo J, Horowitz M, Choi Y. Osteoimmunology, interaction of the bone and immune system. J Endocrine Review 2008;29:403-440.

19. Yoshida T, Sakamoto A, Tsukamoto N, Nakayama K, Iwamoto $Y$. Establishment of an animal model of pasteurized bone graft, with preliminary analysis of muscle coverage or FGF2 administration to the graft. J Orthop Surg Res 2009;4:1-10.

20. Pugh N, Ross SA, El Sohly MA, Pasco DS. Characterization of aloeride, a new high molecular weight polysaccharide from aloe vera with potent immunostimulatory activity. J Agric Food Chem 2001;49:1030-1034.

21. Chaidan P. A study the element in Aloe vera powder by neutron activation analysis, (Thesis). Mahidol University 2005;p 11.

22. Khan SN, Cammisa FP, Sandhu HS, Diwan AD, Girardi FP, Lane JM. The biology of bone grafting. J Am Acad Orthop Surg 2005;13:77-86.

23. Ko YK. The effect of five osteotropic factor on osteoprogerin MRNA expression in gingival fibroblast. J Korean Acad Periodontol 2008;38:395-404.

24. Nanci A, Bosshardt DD. Structure of periodontal tissue in health and disease, Periodontology 2000 2006;40:11-28.

25. Steiner GG, Francis W, Burrell R, Kallet MP, Steiner DM, Macias R. The healing socket and socket regeneration. J Compendium 2008;29:1- 11.

26. Khudhany LS. Determining of density index female mandibular bone post menopause with many risk factor of osteoporosis. (Dissertation). Indonesia University 2003:34 and 52.

27. Riggs BL. The mechanisms of estrogen regulation of bone resorption. J Clin Invest 2000;106:1203-1204. 